\title{
PENGARUH KOMPENSASI DAN DISIPLIN KERJA TERHADAP KINERJA KARYAWAN PT BORWITA CITRA PRIMA CABANG SINGARAJA
}

\author{
Kadek Ayu Warsiti Sundari Dewi ${ }^{1}$, I Nyoman Sujana ${ }^{2}$, Anjuman Zukhri ${ }^{3}$ \\ Jurusan Pendidikan Ekonomi \\ Universitas Pendidikan Ganesha \\ Singaraja, Indonesia
}
e-mail: ayuribka03@gmail.com¹,sujanatbn@yahoo.com ${ }^{2}$, anjumanzukhri09@gmail.com ${ }^{3}$

\begin{abstract}
Abstrak
Penelitian ini bertujuan untuk mengetahuipengaruh kompensasi terhadap kinerja karyawan, pengaruh disiplin kerja terhadap kinerja karyawan, dan pengaruh kompensasi dan disiplin kerja secara simultan terhadap kinerja karyawanPT Borwita Citra Prima Cabang Singaraja. Jenis penelitian ini merupakan penelitian kuantitatif. Data dikumpulkan dengan metode kuesioner. Teknik analisis data menggunakan analisis regresi linier bergandaberbantuanprogram SPSS 16.0 for Windows. Hasil penelitian menunjukkan bahwa secara parsial kompensasi berpengaruh signifikan terhadap kinerja karyawan, yang ditunjukkan dengan nilai probabilitas uji t 0,007 yang lebih kecil dari $\alpha=$ 0,05 ;secara parsial disiplin kerja berpengaruh signifikan terhadap kinerja karyawan, yang ditunjukkan dengan nilai probabilitas uji t 0,000 yang lebih kecil dari $\alpha=0,05$; dan secara simultan kompensasi dan disiplin kerja berpengaruh signifikan terhadap kinerja karyawan, yang ditunjukkan dengan nilai probabilitas uji $F 0,000$ yang lebih kecil dari $\alpha=$ 0,05 .
\end{abstract}

Kata kunci: kompensasi, disiplin kerja, kinerja karyawan.

\begin{abstract}
This research was aimed to identify the effect of compensation on employee performance, the effect of work discipline on employee performance, and the effect of compensation and work discipline simultaneously onemployee performanceof PT Borwita Citra Prima Cabang Singaraja.This researchwas quantitative research. The data collected by questionnaires. Data analysis technique using multiple linear regression analysis assisted program SPSS 16.0 for Windows. The results showed thatpartially compensation had a significant effect on the employee performance, as indicated by probability value of $t$ test $0.007<\alpha=0.05$; partially work discipline had a significant effect on the employee performance, as indicated by probability value of t test $0.000<\alpha=0.05$; and simultaneously compensation and work discipline had a significant effect on the employee performance, as indicated by probability value of $F$ test $0.000<\alpha=0.05$.
\end{abstract}

\section{PENDAHULUAN}

Keywords:compensation, work discipline, employee performance.

Perusahaan pada umumnya didirikan dengan tujuan dapat melangsungkan hidupnya untuk memproleh keuntungan yang maksimal. Pengelolaan sumber daya manusia (SDM) sangat penting dalam mencapai tujuan suatu permasalahan.
Masalah sumber daya manusia saat ini masih tetap menjadi pusat perhatian bagi suatu perusahaan untuk bertahan di era globalisasi dalam menghadapi Masyarakat Ekonomi ASEAN (MEA) perusahaan dituntut untuk melakukan persaingan usaha yang lebih kompetitif baik dengan pasar 
dalam negeri maupun luar negeri. Untuk menghadapi persaingan tersebut, setiap organisasi harus memiliki sumber daya manusia yang kompeten untuk meningkatkan mutu dan kualitas dalam organsasi untuk memajukan bisnisnya.

Salah satu sumber daya organisasi yang memiliki peran penting dalam mencapai tujuannya adalah sumber daya manusia (Bangun, 2012). Pada dasarnya sumber daya manusia merupakan faktor terpenting sebagai penggerak dalam pelaksanaan seluruh kegiatan yang didasarkan pada kemampuan serta kreativitas yang dimiliki sebagai kebutuhan untuk mencapai tujuan perusahaan. Berahasil tidaknya suatu perusahaan biasanya diketahui dari kemampuan perusahaan tersebut dalam pengelolaan sumber daya manusia yang dimiliki perusahaan agar segala tujuan yang diinginkan tercapai.

Tujuan perusahaan itu tercapai tidak hanya tergantung pada peralatan sarana dan prasarana yang lengkap dan juga harus memiliki visi dan misi untuk mencapai tujuan dan sasaran perusahaan.Tujuan dari perusahaan ini adalah memenuhi kepuasan pelanggan, komitmen terhadap pelayanan umum serta berupaya memberikan hasil terbaik bagi shareholder.namun lebih kepada faktor manusia dalam mencapai suatu tujuan. Setiap karyawan yang memiliki kinerja yang tinggi dan baik dapat berkontribusi untuk mencapai tujuan dan sasaran-sasaran yang telah ditetapkan oleh perusahaan.

Kinerja yang tinggi dapat dibentuk dengan adanya kesadaran setiap pimpinan perusahaan untuk memberikan dukungan kepada karyawan berupa keikutsertaan pimpinan dalam memberikan arahan mengenai pekerjaan yang dilakukan oleh setiap karyawan, dengan demikian karyawan dapat lebih memahami mengenai tanggung jawab pekerjaan yang mereka lakukan. Selain itu, suasana tempat kerja yang nyaman, pemberian motivasi, penciptaan disiplin kerja yang baik dan kompensasi yang sesuai setiap karyawan, akan dapat meningkatkan semangat karyawan dalam bekerja.

Kinerja pada umumnya dikatakan sebagai ukuran bagi Menurut
Mangkunegara (2007), "Kinerja adalah outcome yang dihasilkan secara kualitas dan kuantitas yang dicapai oleh karyawan dalam melaksanakan tugasnya sesuai dengan tanggung jawab yang diberikan kepadanya". Menurut Mathis dan Jackson, (2009), kinerja pada umumnya adalah hasil kerja yang dicapai oleh seseorang atau kelompok orang dalam suatu organisasi, sesuai dengan wewenang dan tanggung jawab masing-masing dalam rangka upaya mencapai tujuan organisasi bersangkutan, secara legal tidak melanggar hukum dan sesuai dengan moral maupun etika.Sementara itu, menurut Mangkuprawira (2007), kinerja adalaha hasil atau tingkat keberhasilan seseorang selama periode tertentu di dalam melaksanakan tugas dibandingkan dengan berbagai kemungkinan seperti standar, hasil kerja, target atau sasaran atau kriteria yang telah ditentukan terlebih dahulu dan telah disepakati bersama. Menurut Suparno (2015:131), "Kinerja adalah tingkat pencapaian hasil atas pelaksanaan tugas tertentu". Berdasarkan berapa pengertian mengenai kinerja yang telah dikemukan menurut para ahli di atas, maka dapat disimpulkan bahwa kinerja adalah hasil kerja atau outcome yang baik secara kualitas dan kuantitas yang dicapai selama periode waktu tertentu dengan wewenang dan tanggung jawab masing-masing dalam mencapai tujuan organisasi bersangkutan.

Rendahnya kinerja karyawan dalam suatu perusahaan dapat dilihat dari besaran gaji maupun tunjangan yang diberikan oleh perusahaan dengan besaran tanggung jawab yang dilakukan selain itu kurangnya loyalitas karyawan terhadap perusahaan membuat kontribusi yang diberikan karyawan kepada perusahaan tidak optimal, dan komunikasi yang kurang baik juga terjadi dikarenakan karakter setiap karyawan yang sulit disatukan. Oleh karena itu, perusahaan masih membutuhkan usaha-usaha yang dapat memaksimalkan kinerja karyawan guna mencapai tujuan perusahaan.

Pencapaian kinerja karyawan dapat melalui penilaian disiplin kerja karyawan.Menurut Sutrisno (2009:86), "Disiplin kerja sebagai suatu sikap kesediaan dan kerelaan seseorang untuk 
mematuhi dan mentaati norma-norma peraturan yang berlaku disekitarnya". Senada dengan para ahli di atas, menurut Juhana dan Haryanti (2013:134), "Disiplin kerja merupakan suatu sikap mematuhi, dan menaati peraturan-peraturan yang berlaku, serta sanggup menjalankan dan siap menerima sanksisanksinya".Sementara itu menurut Singodimedjo (2002), disiplin kerja adalah sikap kesediaan dan kerelaan seseorang untuk mematuhi dan menaati norma-norma peraturan yang berlaku disekitarnya. Sedangkan pendapat berbeda dari para ahli di atas, menurut Rivai dan Sagala (2009:825), "Disiplin kerja adalah suatu alat yang digunakan para manajer untuk berkomunikasi dengan karyawan agar mereka bersedia untuk meningkatkan kesadaran dan kesedian seseorang menaati semua peraturan perusahaan dan norma-norma yang berlaku". Dari beberapa pendapat para ahli di atas, maka dapat disimpulkan bahwa disiplin kerja adalah sikap karyawan dalam mengahargai, menghormati, mematuhi dan menaati peraturan ataua ketentuan yang berlaku dalam suatu organisasi atau perusahaan tempat merka bekerja.

Disiplin sangat diperlukan dalam rangka meningkatkan kinerja karyawan. Disiplin disini berarti sifat ketaatan dan kepatuhan pada aturan yang berlaku yang ditetapkan oleh perusahaan. Adapun pendapat yang dikemukakan oleh Hasibuan (2012:193) menyatakan bahwa "Semakin baik disiplin kerja seorang karyawan, maka semakin tinggi hasil kinerja yang akan dicapai." Senada dengan itu, Mangkuprawira (2007:122) menyatakan bahwa“Disiplin kerja sangat mempengaruhi kinerja karyawan, hal ini disebabkan karena disiplin merupakan bentuk-bentuk latihan bagi karyawan dalam melaksanakan aturan-aturan perusahaan". Semakin disiplin karyawan semakin tinggi kinerja karyawan.

Faktor lain yang berpengaruh terhadap kinerja adalah kompensasi yang diberikan kepada karyawan. Menurut Sutrisno (2009), pemberian kompensasi yang layak bukan saja dapat mempengaruhi kondisi materi para karyawan, tetapi juga dapat menentramkan batin karyawan untuk bekeja lebih tekun dan mempunyai inisiatif. Apriani (2012:3) mendefinisikan "Kompensasi adalah penghargaan/imbalan langsung maupun tidak langsung yang adil dan layak kepada karyawan sebagai balasan atas kontribusi mereka terhadap pencapaian tujuan organisasi". Sependapat dengan pandangan di atas Rachmawati (2011:160) menyatakan bahwa "Kompensasi/ upah adalah imbalan atas jasa yang dapat berbentuk secara langsung (berbentuk uang), atau secara tidak langsung (asuransi kesehatan, fasilitas liburan)". Menurut Santoso (2012), kompensasi adalah semua bentuk upah/ imbalan yang mempunya dua komponen yaitu ada pembayaran keuangan langsung ada pembayaran tidak langsung. Pada prinsipnya, pemberian kompensasi itu merupakan hasil penjualan tenaga para sumber daya manusia (SDM) terhadap perusahan. Namun dalam hal ini terkandung pula pengertian bahwa para karyawan telah memberikan segala kemampuan kerjanya kepada perusahaan, maka perusahaan sewajarnya menghargai jerih payah karyawan itu dengan cara memberikan balas jasa yang setimpal kepada mereka.

Kompensasi sangat diperlukan dalam rangka meningkatkan kinerja karyawan. MenurutHasibuan (2012:118), "Pemberian kompensasi yang semakin baik akan mendorong karyawan untuk bekerja dengan semakin baik dan produktif". Menurut Mulyadi (2005), kurangnya pemberian kompensasi dapat menyebabkan rendahnya kinerja karyawan. Perusahaan tidak dibenarkan memberikan upah yang tidak sesuai dengan pedoman yang ditetapkan oleh pemerintah, yaitu harus sesuai dengan persyaratan yang tercantum dalam Upah Minimum Kabupaten (UMK). Penggajian harus memperhatikan peraturan pemerintah, seperti ketentuan tentang Upah Minimum Kabupaten (UMK). Jika upah yang diterima karyawan lebih rendah dari UMK, maka karyawan kurang maksimal dalam memberdayakan diri untuk bekerja.

Kompensasi kerja adalah suatu penghargaan dalam bentuk uang yang diberikan oleh pihak pemimpin perusahaan kepada karyawan agar mereka bekerja dengan motivasi tinggi dan berprestasi 
dalam mencapai tujuan-tujuan organisasi. Kompensasi diartikan sebagai bentuk pembayaran langsung yang didasarkan atau dikaitkan langsung dengan kinerja dan diartikan sebagai pemberian keuntungan bagi karyawan akibat peningkatan produktivitas atau penghematan biaya. Adanya karyawan yang disiplin dan pemberian kompensasi yang sesuai diharapkan dapat meningkatkan kinerja karyawan. Meningkatnya kinerja karyawan secara keseluruhan pada suatu perusahaan akan meningkatkan pula kelancaran proses kerja dan dengan kelancaran proses kerja akan mempermudah tercapainya tujuan dari organisasi yang bersangkutan.

Saat ini karyawan menyatakan ketidakpuasannya atas gaji yang tidak sesuai dengan kesepakatan pembayaran, bonus yang diharapkan tidak sesuai dengan loyalitas seorang karyawan terhadap perusahaan dan tunjangan kesehatan yang disediakan oleh perusahaan kurang mencukupi. Pemberian kompensasi ini dapat memberikan suatu dorongan bagi karyawan untuk bekerja lebih baik lagi dan membuatnya lebih loyal terhadap perusahaan. Tidak dapat dipungkiri pada saat ini kompetisi antar perusahaan sangatlah ketat, perusahaan dituntut mampu untuk bersaing secara sehat dan itu semua harus ditunjang dengan sumber daya manusia yang berkualitas.

PT Borwita Citra Prima memiliki peranan penting dalam meningkatkan mutu dan sumber daya manusia yang dihasilkan.Untuk mencapai semua itu tidak terlepas dari masalah kompensasi yang berhubungan dengan peningkatan kinerja karyawan, idealnya perusahaan harus memberikan kompensasi yang layak kepada setiap karyawan sesuai dengan tanggung jawab pekerjaan yang diberikan, kemudian untuk memproleh karyawan yang berkualitas perusahaan harus mencanangkan program kompensasi yang menarik agar calon karyawan yang datang memiliki kualifikasi sesuai dengan yang dibutuhkan perusahaan.

Perusahaan PT Borwita Citra Prima ini merupakan perusahaan yang beroperasi di bidang goods. Perusahaan ini menjadi distributor produk-produk terkenal seperti
P\&G dan Gillete. PT Borwita Citra Prima yang terletak di jalan pulau komodo,gang Rama Singaraja. PT Borwita Citra Prima beberapa fenomena yang terjadi terkait dengan rendahnya kedisiplinan dan kompensasi yang diterima oleh karyawan. dari 10 karyawan yang dijadikan sampel awal dari permasalahan tersebut. Ketidak disiplinan karyawan yang terjadi adalah pada saat karyawan masuk bekerja masih ada karyawan yang datang terlambat dari aturan yang ditetapkan yaitu pukul 08.00 bahkan pulang terlalu cepat dari peraturan yang sudah ditetapkan pukul 17.00, istirahat kerja yang diberikan perusahaan juga masih sering dilanggar dengan kedatangan karyawan ke kantor lebih dari jam istirahat yang ditetapkan yaitu pukul 12.00 sampai dengan 13.30 .

Perusahaan PT Borwita Citra Prima begerak dibidang distributor, oleh karena itu karyawan harus memiliki ketelitian yang tinggi agar dapat bersaing dengan perusahaan sejenis, akan tetapi yang terjadi pada PT. Borwita Citra Prima Cabang Singaraja ketelitian yang dimiliki karyawan masih dibawah standar sehingga berimbas kurang baiknya tingkah laku karyawan, dari pelanggaran kedisiplinan yang telah terjadi biasanya karyawan mendapatkan teguran dari atasan apabila karyawan diketahui tiga kali melakukan pelanggaran, akan tetapi karyawan tidak mempunyai rasa takut terhadap teguran dari atasan tersebut.Jika permasalahan ini tidak diberikan solusi, maka bisa saja akan ditiru oleh karyawan-karyawan lain dan setiap karyawan menjadi tidak disiplin dengan peraturan yang sudah ditetapkan. Bahkan dengan adanya permasalahan ini akan berdapak pada prestasi kerja karyawan jika dibiarkan secara berkelanjutan.

Permasalahan tersebut memberikan indikasi bahwa kompensasi dan disiplin kerja berpengaruh terhadap kinerja karyawan. Hal tersebut menunjukkan bahwa kompensasi dan disiplin kerja sangat penting dalam memperbaiki masalah rendahnya kinerja karyawan. Oleh karena itu, dalam penelitian ini ditetapkan kompensasi dan disiplin kerja sebagai variabel independen, dan kinerja karyawan sebagai variabel dependen. Berdasarkan 
uraian pada latar belakang penelitian di atas, maka dipandang perlu untuk melakukan penelitian yang berjudul "Pengaruh Kompensasi dan disiplin kerja terhadap kinerja karyawan PT Borwita Citra Prima Cabang Singaraja."Penelitian ini bertujuan untuk mengetahui: (1) pengaruh kompensasi terhadap kinerja karyawan, (2) pengaruh disiplin kerja terhadap kinerja karyawan, dan (3) pengaruh kompensasi dan disiplin kerja secara simultan terhadap kinerja karyawanPT Borwita Citra Prima Cabang Singaraja.

\section{METODE}

Penelitian ini merupakan jenis penelitian kausal. Penelitian kausal adalah penelitian yang menunjukkan hubungan variabel bebas dengan variabel terikat (Sugiyono, 2011). Terdapat tiga variabel yang digunakan dalam penelitian ini yaitu dua variabel bebas dan satu variabel terikat. Variabel bebas dalam penelitian ini adalah adalah kompensasi $\left(X_{1}\right)$ dan disiplin kerja $\left(X_{2}\right)$, sedangkan variabel terikat dalam penelitian ini adalah kinerja karyawan $(Y)$.

Subjek penelitian ini adalah karyawan PT Borwita Citra Prima Cabang Singaraja yang bejumlah 38 orang,sedangkan yang menjadi objek dalam penelitian ini adalah kompensasi, disiplin kerja, dan kinerja karyawan. Jenis data penelitian ini adalah data kuantitatif, yaitu data berupa angkaangka yang diperoleh dari jawaban responden mengenai kuesioner kompensasi, disiplin kerja, dankinerja karyawan. Data primer adalah data yang diperoleh langsung dari subjek yang diteliti. Data primer penelitian ini berupa kuesioner kompensasi, disiplin kerja, dan kinerja karyawan.

Adapun metode pengumpulan data yang digunakan dalam penelitian ini adalah metode kuesioner. Metode kuesioner digunakan untuk mendapatkan data tentang kompensasi, disiplin kerja, dankinerja karyawan. Data yang telah dikumpulkan digunakan sistem skor, dimana jawaban pertanyaan diberi skor dengan menggunakan skala likert. Skala likert merupakan skala yang digunakan untuk mengukur, sikap, pendapat, dan persepsi seseorang atau sekelompok orang tentang fenomena sosial (Sugiyono, 2013). Setiap pernyataan disediakan 5 (lima) alternatif jawaban, yaitu (1) apabila jawaban sangat sesuai diberi skor 5 , (2) apabila jawaban sesuai diberi skor 4, (3) apabila jawaban cukup sesuai diberi skor 3 , (4) apabila jawaban tidak sesuai diberi skor 2, dan (5) apabila jawaban sangat tidak sesuai diberi skor 1.

Kuesioner sebagai instrumen pengumpulan data terlebih dahulu harus diuji tingkat validitas dan reliabilitasnya. Untuk menguji tingkat validitas dan reliabilitas instrumen penelitian akan diujikan kepada 30 responden. Validitas adalah untuk melihat kecermatan alat ukur, yaitu mengukur apa yang akan diukur. Dalam penelitian ini, suatu kuesioner dinyatakan valid, jika pertanyaan maupun pernyataan pada kuesioner mampu untuk mengungkapkan sesuatu yang akan diukur oleh kuesioner tersebut. Pengujian validitas dalam penelitian ini dilakukan dengan menggunakan Person Correlation yang terdapat dalam program SPSS 16.0 for Windows. Suatu pertanyaan dikatakan valid jika tingkat signifikasinya di bawah 0,05. Reliabilitas berkaitan dengan keterandalan suatu indikator. Informasi yang ada pada indikator ini tidak berubah-ubah, atau bisa disebut dengan kosisten. Uji reabilitas dilakukan untuk menguji apakah jawaban dari responden konsisiten. Suatu angket dikatakan reliable jika jawaban seseorang terhadap pertanyaan adalah konsisten atau stabil dari waktu ke waktu. Pengujian realibilitas dalam penelitian ini dilakukan dengan menggunakan Alpha Cronbach yang terdapat dalam program SPSS 16.0 for Windows. Suatu instrumen dikatakan reliabel jika memiliki nilai Alpha Cronbach > 0,60 .

Analisis data dilakukan untuk menguji hipotesis yang diajukan, yaitu untuk mengetahui ada tidaknya hubungan antara variabel bebas $(X)$ dengan variabel terikat $(Y)$, sedangkan teknik analisis data yang digunakan dalam penelitian ini adalah analisis regresi linier berganda. Regresi linier berganda digunakan untuk mengetahui pengaruh antara dua variabel bebas atau lebih terhadap variabel terikat (Sugiyono, 2011). Sebelum dilakukan pengujian analisis regresi linear berganda, maka dilakukan uji asumsi klasik, yang 
terdiri dari uji normalitas, uji heteroskedastisitas, dan uji multikolinearitas.

Teknik analisis data yang digunakan adalah analisis regresi linier berganda. Dari hasil analisis regresi linier berganda dapat diketahui persamaan garisregresisebagai berikut.

$$
Y=a+\beta_{1} X_{1}+\beta_{2} X_{2}+\varepsilon
$$

Keterangan:

$\mathrm{Y}=$ Kinerja karyawan

$\alpha \quad=$ Koefisien konstanta

$\beta_{1}, \beta_{2}=$ Koefisien regresi

$\mathrm{X}_{1}=$ Kompensasi

$\mathrm{X}_{2}=$ Disiplin kerja

$\varepsilon=$ Error

Pengujian hipotesis secara parsial menggunakan uji t. Uji t dilakukan untuk melihat signifikansi pengaruh independen secara individu terhadap variabel dependen. Pengujian ini dilakukan dengan membandingkan $t_{\text {hitung }}$ dengan $t_{\text {tabel. }}$. Adapun langkah-langkah pengujiannya, yaitu: (1) perumusan hipotesis, (2) menentukan tingkat signifikan (a) yaitu sebesar 5\%, (3) menentukan kriteria penerimaan atau penolakan $\mathrm{H}_{0}$ dengan melihat nilai signifikan. Jika signifikan $<5 \%$ maka $\mathrm{H}_{0}$ ditolak dan jika signifikan $>5 \%$ maka $\mathrm{H}_{0}$ diterima, dan (4) pengambilan keputusan penelitian.

Pengujian hipotesis secara simultan menggunakan uji F. Uji $F$ dilakukan untuk melihat signifikansi pengaruh independen secara simultan terhadap variabel dependen. Pengujian ini dilakukan dengan membandingkan $F_{\text {hitung }}$ dengan $F_{\text {tabel }}$. Adapun langkah-langkah pengujiannya, yaitu: (1) perumusan hipotesis, (2) menentukan tingkat signifikan (a) yaitu sebesar 5\%, (3) menentukan kriteria penerimaan atau penolakan $\mathrm{H}_{0}$ dengan melihat nilai signifikan. Jika signifikan $<5 \%$ maka $\mathrm{H}_{0}$ ditolak dan jika signifikan > 5\% maka $\mathrm{H}_{0}$ diterima, dan (4) pengambilan keputusan penelitian.

Analisis determinasi bertujuan untuk mengetahui atau menentukan seberapa besar pengaruh kompensasi dan disiplin kerja terhadap kinerja karyawan. Untuk menghitung koefisien determinasi $\left(R^{2}\right)$ menggunakan program SPSS 16.0 for Windows.

\section{HASIL DAN PEMBAHASAN}

Hasil analisis data menunjukkan bahwa secara parsial pengaruh kompensasi terhadap kinerja karyawanPT Borwita Citra Prima Cabang Singaraja dapat diketahui dengan menggunakan uji t. Perhitungan uji $\mathrm{t}$ menggunakan bantuan program SPSS 16.0 for Windows dan pengujian hipotesis dilakukan pada taraf signifikansi $5 \%$. Hasil uji t dapat dilihat pada Tabel 1 berikut.

Tabel 1. Hasil Uji tuntuk PengaruhKompensasiTerhadap Kinerja Karyawan

\begin{tabular}{|c|c|c|c|c|c|c|}
\hline \multirow{2}{*}{\multicolumn{2}{|c|}{ Model }} & \multicolumn{2}{|c|}{$\begin{array}{c}\text { Unstandardized } \\
\text { Coefficients }\end{array}$} & \multirow{2}{*}{$\begin{array}{c}\text { Standardized } \\
\text { Coefficients } \\
\text { Beta }\end{array}$} & \multirow[t]{2}{*}{$\mathrm{t}$} & \multirow[t]{2}{*}{ Sig. } \\
\hline & & B & Std. Error & & & \\
\hline 1 & $\begin{array}{l}\text { (Constant) } \\
\text { Kompensasi }\end{array}$ & $\begin{array}{l}13,901 \\
0,391\end{array}$ & $\begin{array}{l}4,525 \\
0,137\end{array}$ & 0,428 & $\begin{array}{l}3,072 \\
2,843\end{array}$ & $\begin{array}{l}0,004 \\
0.007\end{array}$ \\
\hline
\end{tabular}

a. Dependent Variable: Kinerja karyawan

Berdasarkan Tabel 1, diperoleh nilai $t_{\text {hitung }}=2,843$ dengan nilai $p$-value sebesar 0,007 . Nilai $p$-value sebesar 0,007 lebih kecil dari $\alpha=0,05$, maka keputusannya $\mathrm{H}_{0}$ ditolak. Jadi, dapat disimpulkan bahwa secara parsial terdapat pengaruh yang signifikan antara kompensasi terhadap kinerja karyawan PT Borwita Citra Prima Cabang Singaraja.
Hasil analisis data menunjukkan bahwa secara parsial pengaruhdisiplin kerjaterhadap kinerja karyawanPT Borwita Citra Prima Cabang Singaraja dapat diketahui dengan menggunakan uji t. Perhitungan uji $\mathrm{t}$ menggunakan bantuan program SPSS 16.0 for Windowsdan pengujian hipotesis dilakukan pada taraf signifikansi 5\%. Hasil uji t dapat dilihat pada Tabel 
Tabel 2. Hasil Uji tuntuk PengaruhDisiplin KerjaTerhadap Kinerja Karyawan

\begin{tabular}{|c|c|c|c|c|c|c|}
\hline & \multirow{3}{*}{ Model } & \multicolumn{2}{|c|}{ Unstandardized } & \multicolumn{3}{|l|}{ Standardized } \\
\hline & & \multicolumn{2}{|c|}{ Coefficients } & Coefficients & $T$ & Sig. \\
\hline & & $\mathrm{B}$ & Std. Error & Beta & & \\
\hline \multirow[t]{2}{*}{1} & \multirow{2}{*}{$\begin{array}{l}\text { (Constant) } \\
\text { Disiplin }\end{array}$} & 5,173 & 2,831 & & 1,775 & 0,084 \\
\hline & & 0,644 & 0,083 & 0,790 & 7,736 & 0,000 \\
\hline
\end{tabular}

a. Dependent Variable: Kinerja karyawan

Berdasarkan Tabel 2, diperoleh nilai $t_{\text {hitung }}=7,736$ dengan nilai $p$-value sebesar 0,000 . Nilai $p$-value sebesar 0,000 lebih kecil dari $\alpha=0,05$, maka keputusannya $\mathrm{H}_{0}$ ditolak. Jadi, secara parsial terdapat pengaruh yang signifikan antara disiplin kerjaterhadap kinerja karyawan PT Borwita Citra Prima Cabang Singaraja.

Pengaruh kompensasi dan disiplin kerja terhadap kinerja karyawanPT Borwita Citra Prima Cabang Singaraja secara simultandiuji dengan uji F.Perhitungan uji $F$ menggunakan bantuan program SPSS 16.0 for Windows dan pengujian hipotesis dilakukan pada taraf signifikansi $5 \%$. Hasil uji $F$ dapat dilihat pada Tabel 3 .

Tabel 3. Hasil Uji F Pengaruh Kompensasidan Disiplin Kerja Terhadap Kinerja Karyawan

\begin{tabular}{llccccc} 
& \multicolumn{6}{c}{ ANOVA } \\
\cline { 2 - 6 } & Model & Sum of Squares & $d f$ & Mean Square & F & Sig. \\
\hline 1 & Regression & 545,278 & 2 & 272,639 & 36,483 & 0,000 \\
& Residual & 261,558 & 35 & 7,473 & & \\
& Total & 806,836 & 37 & & & \\
\hline
\end{tabular}

a. Dependent Variable: Kinerja karyawan

b. Predictors: (Constant), Disiplin kerja, Kompensasi

Berdasarkan Tabel 3, diperoleh nilai $F_{\text {hitung }}=36,483$ dengan nilai $p$-value sebesar 0,000 . Nilai $p$-value 0,05 , sehinggasecara simultan ada pengaruh yang signifikan antara kompensasi dan disiplin kerja terhadap kinerja karyawan PT Borwita Citra Prima Cabang Singaraja.

Besar pengaruh kompensasi dan disiplin kerja terhadap kinerja karyawanPT Borwita Citra Prima Cabang Singarajadapat diketahui dari koefisien determinasi, yang ditunjukkan dengan nilai Adjusted $\mathrm{R}$ Square. Hasil analisis koefisien determinasi disajikan pada Tabel 4.

Tabel 4. Hasil Analisis Koefisien Determinasi

\begin{tabular}{ccccc}
\hline Model & $\mathrm{R}$ & $\mathrm{R}$ Square & $\begin{array}{c}\text { Adjusted } \\
\mathrm{R} \text { Square }\end{array}$ & $\begin{array}{c}\text { Std. Error of } \\
\text { the Estimate }\end{array}$ \\
\hline 1 & 0,822 & 0,676 & 0,657 & 2,73369 \\
\hline
\end{tabular}

a. Predictors: (Constant), Disiplin kerja, Kompensasi

Berdasarkan Tabel4 ditunjukkan bahwa besar hasil perhitungan koefisien determinasi pada pengaruh kompensasi dan disiplin kerja terhadap kinerja karyawanPT Borwita Citra Prima Cabang Singaraja secara simultan sebesar0,676. Dengan demikian, besarnya sumbangan pengaruh untuk variable kompensasi dan disiplin kerja terhadap kinerja karyawan secara simultan adalah sebesar $67,6 \%$, sedangkan sisanya sebesar $32,4 \%$ dipengaruhi oleh factor lain yang tidak termasuk dalam penelitian ini.

Berdasarkan hasil analisis regresi linier berganda, dapat diketahui persamaan garis regresi untuk mengetahui pengaruh 
kompensasi dan disiplin kerja terhadap kinerja karyawanPT Borwita Citra Prima Cabang Singarajadengan menggunakan analisis koefisien beta. Hasil perhitungan konstanta dan koefisien beta dapat dilihat pada
Tabel

Tabel 5. Hasil Analisis Koefisien Beta

\begin{tabular}{|c|c|c|c|c|c|c|}
\hline & \multirow[t]{2}{*}{ Model } & \multicolumn{2}{|c|}{$\begin{array}{l}\text { Unstandardized } \\
\text { Coefficients }\end{array}$} & \multirow{2}{*}{$\begin{array}{c}\text { Standardized } \\
\text { Coefficients } \\
\text { Beta }\end{array}$} & \multirow[t]{2}{*}{$\mathrm{t}$} & \multirow[t]{2}{*}{ Sig. } \\
\hline & & $\mathrm{B}$ & Std. Error & & & \\
\hline \multirow[t]{3}{*}{1} & (Constant) & -225 & 3,483 & &,- 073 & 0,942 \\
\hline & Kompensasi & 0,215 & 0,091 & 0,235 & 2,356 & 0,024 \\
\hline & Disiplin & 0,594 & 0,081 & 0,728 & 7,292 & 0,000 \\
\hline
\end{tabular}

a. Dependent Variable: Kinerja karyawan

Berdasarkan perhitungan regresi linier berganda pada Tabel 5, maka didapat hasil persamaan regresi sebagai berikut.

$$
\begin{aligned}
& Y=a+\beta_{1} X_{1}+\beta_{2} X_{2}+\varepsilon \\
& Y=-225+0,215 X_{1}+0,594 X_{2}+\varepsilon
\end{aligned}
$$

Berdasarkan model persamaan regresi yang terbentuk, dapat diinterpretasikan hasil bahwa konstanta sebesar -225 menunjukan jika variabel kompensasi $\left(X_{1}\right)$ dan disiplin kerja $\left(X_{2}\right)$ bernilai konstan atau nol, maka variabel kinerja karyawan (Y) memiliki nilai positif sebesar -225. Selanjutnya, variabel kompensasi $\left(\mathrm{X}_{1}\right)$ memiliki koefisien positif sebesar 0,215 dan variabel disiplin $\operatorname{kerja}\left(\mathrm{X}_{2}\right)$ memiliki koefisien positif sebesar 0,594. Nilai koefisien regresi yang positif menunjukkan bahwa kompensasi $\left(X_{1}\right)$ dan disiplin $\operatorname{kerja}\left(\mathrm{X}_{2}\right)$ berpengaruh positif terhadap kinerja karyawan (Y). Hal ini menggambarkan bahwa peningkatan kompensasi $\left(X_{1}\right) \quad$ dandisiplin $\operatorname{kerja}\left(X_{2}\right)$ sebesar satu satuan akan dapat meningkatkan kinerja karyawan $(Y)$ sebesar nilai koefisien beta masing-masing variabel bebas dikalikan dengan besar kenaikan yang terjadi.Misalnya, setiap terjadi kenaikan kompensasi $\left(X_{1}\right)$ sebesar satu satuan, maka akan meningkatkan kinerja karyawan $(Y)$ sebesar 0,215 dan setiap terjadi kenaikandisiplin $\operatorname{kerja}\left(\mathrm{X}_{2}\right)$ sebesar satu satuan, maka akan meningkatkan kinerja karyawan (Y) sebesar 0,294. Hal ini menunjukkan bahwa semakin tinggi kompensasi yang diberikan dan disiplin kerja, maka semakin tinggi jugakinerja karyawan. Sebaliknya, semakin rendah kompensasi yang diberikan dan disiplin kerja karyawan, maka semakin rendah juga kinerja karyawan.

Penelitian mengenai pengaruh variabel kompensasi terhadap kinerja karyawan menunjukan bahwa ada pengaruh yang positif dan signifikan pada perusahaan PT Borwita Citra Prima Cabang Singaraja. Hasil penelitian ini didukung oleh teori dari Rivai (2005) yang menyebutkan bahwa kompensasi merupakan sesuatu yang diterima oleh karyawan sebagai ganti kontribusi jasa mereka pada perusahaan, semakin banyak kompensasi yang mereka dapatkan maka kontribusi yang diberikan oleh karyawan akan semakin banyak, dengan kata lain semakin banyak kompensasi yang mereka dapatkan maka kinerjapun akan semakin meningkat. Hasil penelitian ini sejalan dengan hasil penelitian yang dilakukan Suwati (2013) yang menyatakan bahwa kompensasi berpengaruh secara signifikan terhadap kinerja karyawan.

Dari hasil penelitian menunjukkan bahwa terdapat pengaruh yang positif antara variabel disiplin kerja terhadap kinerja karyawan PT Borwita Citra Prima Cabang Singaraja. PT Borwita Citra Prima Cabang Singaraja selalu berupaya untuk meningkatkan tingkat kedisiplinan karyawan, salah satunya dengan upaya absensi atau kehadiran yaitu menjaga agar karyawan selalu bekerja datang kekantor secara tertib, tepat waktu dan teratur sesuai aturan yang ada di perusahaan. Dengan kata lain, aturan yang telah ditetapkan di PT Borwita Citra Prima Cabang Singaraja 
harus dipelihara dan dipertahankan untuk menjaga tingkat kedisiplinan karyawan sehingga hal ini akan berpengaruh positif terhadap kinerja karyawan. Hasil penelitian ini menunjukkan bahwa disiplin kerja berpengaruh positif dan signifikan terhadap kinerja. Hasil penelitian ini sejalan dengan hasil penelitian Riyadi (2016). yang mengemukakan bahwa untuk meningkatkan kinerja faktor yang penting dalam manajemen sumber daya manusia adalah peningkatkan disiplin. Pendapat yang sejalan dikemukan oleh Mangkuprawira (2007:122) bahwa "Disiplin kerja sangat mempengaruhi kinerja karyawan, hal ini disebabkan karena disiplin merupakan bentuk-bentuk latihan bagi karyawan dalam melaksanakan peraturanperaturan perusahaan". Hasil penelitian ini sesuai dengan kajian empirik dari Abidin (2013) yang menyatakan bahwa disiplin kerja berpengaruh positif dan signifikan terhadap kinerja karyawan. Karena semakin tinggi disiplin kerja karyawan maka semakin tinggi kinerjanya. Alasan ini diperkuat oleh teori Selanjutnya dalam penelitian Rivai (2005) mengatakan bahwa disiplin kerja adalah suatu alat yang digunakan para manajer untuk berkomunikasi dengan karyawan agar mereka bersedia untuk mengubah suatu perilaku serta sebagai suatu upaya untuk meningkatkan kesadaran dan kesediaan seseorang menaati semua peraturan perusahaan dan norma-norma sosial yang berlaku.

Berdasarkan hasil penelitian yang telah dilakukan menunjukkan bahwa ada pengaruh positif dan signifikan secara bersama-sama atau simultan dari kompensasi dan disiplin kerja terhadap kinerja karyawan pada perusahaan PT Borwita Citra Prima Cabang Singaraja. Temuan penelitian ini memiliki implikasi bahwa untuk meningkatkan kinerja karyawan perusahaan harus memperhatikan sistem pemberian kompensasi dan disiplin kerja untuk karyawan. Kajian emperik yang turut mendukung temuan penelitian ini adalah hasil penelitian yang dilakukan oleh Utami (2014), yang menyatakan bahwa kompensasi dan disiplin kerja baik secara parsial maupun simultan berpengaruh terhadap kinerja karyawan, karena dengan kompensasi dan disiplin kerja yang tinggi akan meningkatkan kinerja karyawan.

Keterbatasan dari penelitian ini adalah terletak pada pada jumlah sampel yang digunakan dalam penelitian ini masih relative sedikit dan sempit, sehingga diharapkan bagi penelitian yang lain agar melakukan peneliatan selanjutnya dapat mempergunakan subjek yang lebih luas. Selain itu, variabel yang diteliti dalam penelitian ini juga masih sangat terbatas, sehingga disarankan untuk penelitian selanjutnya agar mengkaji dan menguji variabel lain yang diduga kuat dapat mempengaruhi kinerja karyawan.

\section{SIMPULAN DAN SARAN}

Berdasarkan hasil analisis data dan pembahasan hasil penelitian maka dapat ditarik simpulan sebagai berikut. (1) Terdapat pengaruh kompensasi terhadap kinerja karyawan pada perusahaan PT Borwita Citra Prima Cabang Singaraja. bahwa Kompensasi $\left(\mathrm{X}_{1}\right)$ mempunyai nilai $p$ value $0,007<0,05$ maka $\mathrm{Ho}$ ditolak dan $\mathrm{Ha}$ diterima. Artinya, secara parsial variabel kompensasi berpengaruh signifikan terhadap Kinerja. bahwa kompensasi merupakan sesuatu yang diterima oleh karyawan sebagai ganti kontribusi jasa mereka pada perusahaan, semakin banyak kompensasi yang mereka dapatkan maka kontribusi yang diberikan oleh karyawan akan semakin banyak, dengan kata lain semakin banyak kompensasi yang mereka dapatkan maka kinerjapun akan semakin meningkat. (2) Terdapat pengaruh disiplin kerja terhadap kinerja karyawan pada perusahaan PT Borwita Citra Prima Cabang Singaraja. bahwa variabel disiplin $\left(X_{2}\right)$ mempunyai nilai $p$-value $0,000<0,05$ maka Ho ditolak dan Ha diterima. Artinya, secara parsial variabel disiplin $\left(X_{2}\right)$ berpengaruh signifikan terhadap Kinerja. selalu berupaya untuk meningkatkan tingkat kedisiplinan karyawan, salah satunya dengan upaya absensi atau kehadiran yaitu menjaga agar karyawan selalu bekerja datang kekantor secara tertib, tepat waktu dan teratur sesuai aturan yang ada di perusahaan. (3) Terdapat pengaruh kompensasi dan disiplin kerja terhadap kinerja karyawan pada perusahaan PT Borwita Citra Prima Cabang Singaraja, dapat dilihat dari hasil analisis 
ujiF.UjiF menunjukkan analisis regresi linier berganda variabel bebas,yaitu kompensasi $\left(X_{1}\right)$ dan disiplin $\left(X_{2}\right)$ memiliki pengaruh terhadap variable terikat,yaitu kinerja karyawan (Y).bahwa nilai $p$-value lebih kecil dari tingkat signifikansi $5 \%(0,000<0,05)$. Maka Ho ditolak dan $\mathrm{Ha}$ diterima, yang berarti kompensasi dan disiplin kerja secara simultan berpengaruh signifikan terhadap Kinerja karyawan PT Borwita Citra Prima Cabang Singaraja.

Berdasarkan simpulan diatas, maka dapat dikemukakan beberapa saran sebagai berikut. (1) Bagi perusahaan harus lebih meningkatkan pemberian program mengenai reward pada karyawan seperti mengadakan program karyawan terbaik yang dilaksanakan setiap bulan. Program ini akan membantu perusahaan untuk dapat melihat karyawan-karyawan yang memiliki kinerja terbaik dan dapat diberikan reward berupa bonus atau kenaikan jabatan. Selain kompensasi, perusahaan harus tetap memperhatikan mengenai disiplin kerja serta menambahkan beberapa aturan baru berupa sanksi yang tergas terhadap karyawan yang disiplin terutama yang berkaitan dengan pemberian keterangan yang jelas saat tidak masuk. (2) Bagi peneliti selanjutnya yang mengkaji mengenai variabel penelitian serta aspek yang sama yaitu mengenai faktor kompensasi, disiplin kerja dan kinerja karyawan agar mengembangkan penelitian yang luas. Selain itu untuk peneliti lain diharapkan menambah variabel independen lain yang diduga kuat dapat mempengaruhi kinerja karyawan seperti motivasi karyawan dan komitmen karyawan dengan menggunakan kajian empiris serta refrensi yang lebih banyak sehingga dapat membawa kontribusi positif dalam pengembangan ilmu pengetahuan.

\section{DAFTAR PUSTAKA}

Abidin, F.Z. 2013. Pengaruh Disiplin Terhadap Kinerja Karyawan pada PT Rekatama Putra Gegana Bandung. Skripsi tidak diterbitkan. Jurusan Manajemen Fakultas Ekonomi. Universitas Winaya Mukti, Bandung.
Apriani, W. R. 2012. Pengaruh Kompensasi dan Lingkungan Kerja Terhadap Produktivitas Kerja Karyawan PT BPR Restu Artha Makmur Kantor Pusat Majapahit Semarang. Jurnal Universitas Diponegoro Semarang, Vol.1, (No.1) : Hal 252-260.

Bangun, Wilson. 2012. Manajemen Sumber Daya Manusia. Jakarta: Erlangga.

Hasibuan, S. P. 2012. Manajemen Sumber Daya Manusia. Jakarta: PT Bumi Aksara.

Juhana, D.\& Haryati. 2013. Pengaruh Motivasi,Disiplin dan Lingkungan Kerja Terhadap Kinerja Pegawai pada Dinas Kesehatan Kota Cimahi. Jurnal Ekonomi,Bisnis dan Enterpreneuship, Vol. 7, (No.2) : Hal 84-94.

Mangkunegara, A.A. Anwar Prabu.2007. Manajemen Sumber Daya Manusia Perusahaan. Bandung: PT. Remaja Rosdakarya.

Mangkuprawira, Sjafri. 2007. Manajemen Mutu Sumber Daya Manusia. Bogor: Ghalia Indonesia.

Marthis, L. Robert dan Jackson, H. John. 2009. Manajemen Sumber Daya Manusia. Jakarta: Salemba Empat.

Mulyadi. 2005. Akuntansi Biaya. Yogyakarta: Unit Penerbit dan Pecetakan Akademi Manajemen Perusahaan YKPN.

Rachmawati. K. 2011. Analisis Kinerja Karyawan Ditinjau Dari Kompensasi dan Motivasi Kerja Sebagian Variabel Intervining pada PG Soedhono Ngawi. Jurnal Universitas Ngawi, Vol. 8, (No 1) : Hal 160.

Rivai, Veithzal. 2005. Manajemen Sumber Daya Manusia. Jakarta: Raja Grafindo Persada.

Rivai, H. Veithzal dan Sagala, Ella Jauvani. 2009. Manajemen Sumber Daya Manusia Untuk Perusahaan. Jakarta: PT. Raja Grafindo.

Riyadi, Mukhlis. 2016. Pengaruh Motivasi Kerja dan Disiplin Kerja Terhadap Kinerja Karyawan Perusahaan 
Daerah Percetakan Karesidenan Banyumas.Tugas Akhir tidak diterbitkan. Fakultas Ekonomi Universitas Negeri Yogyakarta.

Santoso, A.A. 2012. Pengaruh Kompensasi dan Motivasi Kerja Karyawan pada PDAM Moedal Kota Semarang. Skripsi tidak diterbitkan. Jurusan Administrasi Bisnis, Fakultas IImu Sosial dan IImu Politik, Universitas Diponegoro.

Singodimedjo, Markum, 2002. Manajemen Sumber Daya Manusia. Surabaya: SMMAS.

Sugiyono. 2011. Metode Penelitian Kuantitatif, Kualitatif dan R\&D. Bandung: Alfabeta.

Suparno, E. W. 2015. Manajemen Pengembangan Sumber Daya Manusia. Yogyakarta: Pustaka Pelajar.

Sutrisno, Edi. 2009. Manajemen Sumber Daya Manusia. Jakarta: Kencana Prenada Media Group.

Suwati, Yuli. 2013. Pengaruh Kompensasi dan Motivasi Terhadap Kinerja Karyawan pada PT Tunas Hijau Samarinda. e-Journal Ilmu Administrasi Bisnis, Vol. 1, (No1): Hal 41-55.

Utami, F.M. 2014. Pengaruh Kompensasi dan Disiplin Kerja terhadap Kinerja Karyawan (Studi Kasus pada PT. Gapura Omega Alpha Land, Depok). Skripsi tidak diterbitkan. Jurusan Manajemen Fakultas Ekonomi dan Bisnis Universitas Islam Negeri Syarif Hidayatullah. 